\title{
Merkel Cell Carcinoma by AJCC v7 Stage
}

National Cancer Institute

\section{Source}

National Cancer Institute. Merkel Cell Carcinoma by AJCC v7 Stage. NCI Thesaurus. Code C136869.

A term that refers to the staging of Merkel cell carcinoma (primary cutaneous neuroendocrine carcinoma), following the rules of the TNM AJCC V7 classification system. 